\title{
Exploring Millennials' Perception of Greening Hotels in Egypt
}

\author{
Jailan Mohamed El-Demerdash \\ Associate Professor, Hotel Studies Department \\ Faculty of Tourism and Hotels, Alexandria University
}

\begin{abstract}
"Millennials" is a distinctive and dominant consumer group whose behavior, preferences and purchase decisions are broadly explored but not fully understood yet. Making up the largest market segment in the world, and in Egypt, they have the power to reinvent the hospitality industry and contribute to forming prospective demand for green hotels by showing willingness to adopting their environmental-friendly practices. The current study is one of the first contributions towards

awareness of Egyptian Millennials will not be a significant factor in their acceptance of hotel green practices, as well as, their willingness to pay more for them. However, Millennials' acceptance of hotel green practices level will have an impact on their willingness to pay more.

Millennials were found to have noticeable level of environmental awareness but lack commitment to tolerating hotel green practices and their associated high prices.
\end{abstract} exploring the impact of Millennials on accepting greening hotels in Egypt. Relations among Millennials environment awareness, their acceptance of green practices and willingness to pay more were hypnotized.

The study aims to enhance better understanding Millennials' perception of greening initiatives and to increase the prediction power of their intentions. Millennials' profile, their preferences and environmental decision-making process are brought under light to stimulate actions of hospitality decision-makers and hoteliers. The study questionnaire was composed of four sections and it was distributed to random Egyptian travelers' blogs and facebook groups, with approximately 8000 members. ANOVA test was used examine the study variables. The findings indicated that environmental

Keywords: Millennials, Environment, Awareness, Green Practices and Paying More

\section{Introduction}

The hospitality industry is depending greatly on environmental and cultural resources to offer resource-based activities that constantly interact with the natural systems. Tourism and hospitality industry have the capacity to initiate significant changes in the physical environment. (Elfeel, 2017) .

Tourism's image as a predominantly "smokeless" industry makes its negative impacts seem less defined. However, the industry is now facing increasing scrutiny in relation to the negative environmental and social impacts of its key players, including hotels. (Kasim, 2008) Egyptian tourism and 
hospitality industry is challenged to develop and solicit environmental friendly initiatives, being basically dependent on its unique heritage, beaches and distinctive natural marine environment. (El Demerdash \& Mostafa, 2013) Worldwide, the "greening" of hospitality industry is not a luxury anymore in order to eliminate the negative impacts on the environment by reducing their consumption of resources and by changing their practices. People throughout the world seek to alter the current path of rapid environmental degradation; the hotel industry is not exempt from and has certainly participated in this growing trend. (Kang et al., 2012)

However, attention on relationship between environmental issues and business practices is much more popular in developed countries than in developing ones, either in term of public concern or government policies. According to Mostafa (2007), and Elfeel (2017), consumers in Egypt, as well as in the wider context of the Arab world, are just at the stage of green awakening. Being through different stages of economic development is likely to be an important factor in influencing environmental initiatives and practices. In Egypt, for example, only 103 are green certified from a total of $3524 \& 5$-star hotel; accounting for a percentage of 29\%. (Elfeel, 2017).

Abdel Wahab (2003), Manaktola \& Jauhari (2007), Lita et al. (2014) and Jung et al. (2016) also enlighten that in developing countries, like Egypt, the gap between individuals worried about the Earth and the decision makers is quite large.

It is a fact that customers are the key drivers for the adoption of environmental- friendly practices and often have an influence far beyond any of the other stakeholders. Former studies found that the most common barriers to successful greening attempts were related to customers' knowledge, readiness, preferences and attitudes. (Lee, 2008; Han et al., 2010; Kang et al., 2012, El Demerdash \& Mostafa, 2013 and Li et al, 2017).

In this context, Millennials are expected to reinvent the travel industry with their influential preferences. Research shows that the millennial travelers already make up for over one-third of the world's hotel guests, with predictions that they will reach over 50 per cent by 2020. (Lee, 2008; Caroll, 2016; Bastawroos, 2017; Hamed, 2017 and Johnson, 2017).

Millennials constitutes more than $43 \%$ of the Egyptian population (CAPMAS, 2016), which means leisure and hospitality industry will need to uncover the desires and needs to better attract them. Although, known for being are civic-minded and socially conscious (Lee, 2008; Mboga, 2017 and Attallah \& ElMawardy, 2018), there is still a lack of relevant literature detailing the relationship of the effects of their environmental awareness on consumption behaviors for green hotels. Thus, the current study objectives are to fill the gap in this particular field, enhance better understanding for Egyptian Millennials' perception about greening initiatives in hotels; thereby, increase the prediction power of their intentions. Thus, Millennials' profile, their preferences and environmental decisionmaking process are brought under light in order to stimulate actions of hospitality decision-makers and hoteliers, and provide reliable findings results for academic and corporate perusal. 


\section{Literature Review}

\subsection{Environmental Challenges of Hospitality Industry}

Research argued that hotels consume a considerable amount of water, energy, and disposable products due to the nature of their services and functional characteristic. (Lee, 2008, Han et al., 2010, Han \& Yoon, 2015 and El Demerdash, 2016) F\&B operations are also causing high levels of garbage disposal and rapid diminishing of landfill space. Chemical use and intensive landscape fertilizers can cause atmospheric contamination. (Kasim, 2008) In addition, consumer behavior in the hotel industry generates negative influences on the environment. (Tilikidou et al., 2014 and Han \& Yoon, 2015) Large numbers of tourists are being transported and lodged every single day, putting too much pressure on the physical and human environment of the destination countries. This is a primary cause of the degradation of environmental quality. (Tsai \& Tsai, 2008; Robinot \& Giannelloni, 2010 and Tilikidou et al., 2014) Tourists' experience will negatively affect the natural setting, so that it can be polluted, degraded or lose its aesthetic. (Kasim, 2008) This challenged hospitality industry to respond positively to the principles and practices of sustainable development. In response, greening the industry emerged with the trend of ecological and green hotels.

Green hotels, alternatively called as "environmentally responsible" or "environmentally friendly", are those implanting environmental practices that embrace energy efficiency, water conservation, managing solid waste and recycling attempts. (Manaktola \& Jauhari, 2007; Han \& Yoon, 2015; Green Hotels Association, 2016 and Elfeel, 2017) Other practices may incorporates socio-economic factors into the definition, while highlighting the hotel responsibility towards its employees, the local community, the local culture, and the surrounding ecology" (Han, et al., 2009 and Lita et al., 2014) Green hotels eventually bring various benefits to the operation (e.g., reductions in energy consumption and operational costs, enhancement of the company's image, coping with government regulation, and positive public attention. Moreover, Elfeel (2017) and Chen \& Tung (2010) point to economic and indirect benefits including employee morale and health and safety in the facility.

On the other hand, becoming a green hotel can be the base for a great marketing strategy that helps the hotel to position itself distinctly in the market place. (Manaktola \& Jauhari, 2007) An increasing number of lodging customers who consider various environmental issues are starting to seek and buy eco-friendly products over alternatives, sometimes even paying more for such products; thus, demands for green establishments have been gradually increasing. (Han et al., 2010 and Han \& Yoon, 2015).

However, greening the industry would be difficult if not appreciated and supported by the market, or if tourists do not have the tendency to value hotel attributes based on environmental and social criteria. (Kasim, 2008) Previous research revealed that most tourists still choose hotels based on price, service quality and physical attractiveness rather than environmental and social attributes. (Manaktola \& Jauhari, 2007; Tsai \& Tsai, 2008; Kang et al., 2012 and Elfeel, 2017).

Kang et al. (2012) suggests that customers' approach towards green hotels is complex and contingent, in which different levels of buying behaviors for those hotels vary across different customer segments, product attributes, rates 
and hotel types. As elaborated by Kasim (2008), Han et al. (2010), Lita et al. (2014) and Elfeel (2017), when an individual holds little control over carrying out a certain behavior because of the lack of availability of required resources (e.g., costs or time), his/her behavioral intention will be lower in spite of the fact that he/she has positive attitude concerning the intended act.

In hopes of understanding the customers' approach towards green hotels many researchers investigated the factors involved in influencing their green consumption behaviors. Demographic variables, family life circles, tourist origin and personality traits were considered influential in their studies. (Tsai \& Tsai, 2008; Han et al., 2010; Lita et al., 2014; Harti \& Munandar; 2017 and Naumovska, 2017)

\subsection{Millennials: The Key Drivers}

According to Lee (2008), Han et al. (2010), Mboga (2017), Elfeel (2017) and Attalah \& ElMawardy (2018), demographics can play a significant role in the consumers' intention to purchase green products; this includes gender, educational level, income level and age range.

Millennials, also known as Next Generation and Generation Y, are born in or after 1980s to 2000. They have been watched closely by sociologists and historians for different behaviors and attitudes from those of other generations; they are known for being are civic-minded, socially conscious and experience seekers, particularly in their leisure time. They have environmentally ethical views expressing the moral relationship between humans and their natural environment (Lee, 2008 and Mboga, 2017). Their environmental awareness is meant to value human activities encouraging the protection of the environment. (Tsai \& Tsai, 2008)
Researchers found that well-developed environmentally ethical concepts are influential in shaping green consumption decisions and tolerating sparing green practices. (Sziva \& Zoltay, 2016 and Mboga, 2017) This generation has been growing in a tough environmental and economic climate and they like to feel they are making a difference in the world, therefore, millennial consumers prefer brands that are environmentally-friendly. (Mboga, 2017).

Similarly, in their decision to choose a hotel, Millennials would prefer eco-friendly practices and sustainable efforts, as sustainability is regarded as their popular trend. Although some studies revealed that they want to bring business to proprietor that reflect their own value systems, they might lack similar devotion in their actual conduct and are not yet ready to willing to sacrifice parts of their current lifestyles. (Lee, 2008 and Sziva \& Zoltay, 2016).

In addition, Millennials show a large amount of spending power, because, unlike prior generations, they prefer spending a greater amount of their income on technology and experiences, such as, traveling and dining out. (Naumovska, 2017) The interaction of the total visit experience is vastly important to this generation, as well, as they are willing to pay higher prices if they can be ensured they will have the unforgettable experiences they long for. (Sziva \& Zoltay, 2016) However, they are keen to take advantage of the cheaper travel and accommodation rates, as they are quite sensitive to price. (Caroll, 2016) As smart spenders, Millennials are ready to pay more for products from companies with active socially responsible programs. (Naumovska, 2017 and Attallah \& El-Mawardy, 2018).

Surveys of the World Youth Student and Educational Travel Confederation (WYSETC) 
found that Millennials prefer to travel rather than to save money and to spend money on travelling rather than purchasing precious items (Attallah and El-Mawardy, 2018). Furthermore, they are the generation born with technology at their fingertips, as they post on social media platforms and share experiences with friends while travelling, changing thereby traditional marketing mindsets. (Lee, 2008; Garikapati, et al., 2016 and Harti \& Munandar, 2017)

Bastawroos (2017) and Johnson (2017) discuss how Millennials' expectations and needs toward service are constantly changing, thus, urging hotels to continuously create new services with higher customer value while maintaining a competitive advantage. Therefore, it is of great relevance to know if Millennials, who are making up $43 \%$ of Egyptian population and thus, being key drivers in reinventing Egyptian travel industry; are ready to adopt environmental-friendly style during their hotel accommodation. It is also questionable if their environmental awareness encourages them to tolerate hotel green practices and to pay premium for them. The significance of the current study increases in the light of certain environmental facts in Egypt.

According to the Central Agency for Public Mobilization and Statistics (CAPMAS, 2016) Egypt's ranking in the evidence of environmental performance at the international level declined from 110 to 117 throughout the years from 2008 to 2014, and the individual proportion of Carbon dioxide harmful emissions doubled within the last fifteen years.

Based on the aforementioned theoretical review, the current study formulated the following hypotheses:
H1. Being a Millennial is significantly related to environmental awareness.

H2. Being a Millennial is significantly related to acceptance of hotel green practices

H3. Being a Millennial is significantly related to willingness to pay more for hotel green practices

H4. Millennials' environmental awareness level will significantly impact their acceptance of hotel green practices.

H5. Millennials' environmental awareness level will significantly impact their willingness to pay more.

H6. Millennials' acceptance of hotel green practices level will significantly impact their willingness to pay more.

\section{Methodology}

\subsection{Measures}

The questionnaire used in this study was composed of four sections: the first section contained questions for demographic information, including age range, marital status, income and education degree, as well as, previous stay in hotels with green practices. The second section included items assessing environmental awareness of respondents, the third section consisted of items assessing respondents' readiness to accept hotel green practices, and the fourth one examined their readiness to pay more for a hotel that engages in green practices. For the second, third and fourth construct a 5-point Likert scale was used, from (1) extremely disagree to (5) extremely agree.

This study adopted existing validated items to assess the study variables, as follows: Items assessing environmental awareness of respondents were derived from Tsai \& Tsai (2008), Kang et al. (2012) and Han \& Yoon 
(2015); as they referred to the New Ecological Paradigm (NEP) scale. The NEP scale measures the environmental attitudes, beliefs, and values and encompasses 15 question items. The NEP has been considered the most widely used as a generalized measurement of environmental beliefs and concerns that affect human behavior.

Items assessing respondents' readiness to accept hotel green practices were derived from Manaktul \& Jauharia (2007), Tsai \& Tsai (2008), Lee (2008) and Han et al. (2009). It included 14 items covering, energy, water and recycling green practices. The (WTP - willing to pay) statements were derived from Manaktula \& Jauhari (2007), Han et al., (2009) and Kang et al. (2012). In the opening of the questionnaire, instructions of this survey and a thorough explanation of the study idea were given, including the definition of green hotels.

\subsection{Data Collection and Sample profile}

The total population for this study was Egyptian hotel guests. A Web-based survey was used to collect data. Questionnaires were sent to random Egyptian travelers' blogs and facebook groups, with approximately 8000 members. Only responses from guests previously stayed in 4 and 5-star hotels were included in the study sample, as hotels in less categories were not implementing organized green or environmentally practices. (Elfeel, 2017) A total of 440 usable responses were received from participants. In the usable sample of 440, approximately $61 \%$ of respondents were Millennials, i.e. from 18 to 38 years old and $34 \%$ were between 39 and 50 years old. Fifty percent were married and obtained faculty degrees. Their family income ranged from 6000-11000 to 12000-17000, with $50 \%$ and $18.2 \%$, respectively. The majority (78.6\%) reported that they previously stayed in hotels with green practices.

\section{Results and Discussion}

The research objective to enhance better understanding for Egyptian Millennials' perception about greening initiatives in hotels was met through the study findings. Hypotheses 1, 2 and 3 anticipated that being a millennial is significantly related to environmental awareness, to acceptance of hotel green practices and to willingness to pay more for hotel green practices. Table (1) shows how ANOVA test was used to compare Millennials' environmental awareness to NonMillennials. The results indicated that Millennials showed higher means in twelve statements out of fifteen. However, no significant difference was depicted in this construct between both groups (Sig. $=0.220$ and $F=1.552$ ). Thus, H1: "Being a Millennial is significantly related to environmental awareness" can be partially supported. The findings come in agreement with the study of Elfeel (2017) on Egyptian green hotels. In her study hotel managers saw that customers, regardless of their age range, would rank "concern for the environment" as the least important factor influencing their choice for a hotel, while "quality of service" and "price" came in the first and the second rank, respectively.

The most apparent variations between both groups' responses were depicted in statements (9) "The so-called "ecological crisis" facing humankind has been greatly exaggerated" and statement (11) "Humans were meant to rule over the rest of nature".

It was also obvious that Millennials showed a higher level of acceptance of hotel green practices compare to other age groups with a significant difference $=0.047$. Thus, H2: "Being a Millennial is significantly related to acceptance of hotel green practices" can be supported. 
Table 1: Comparing Millennials to other age groups using ANOVA

\begin{tabular}{|c|c|c|c|c|c|c|}
\hline \multirow{2}{*}{ Research Variables } & \multicolumn{2}{|c|}{ Millennial } & \multicolumn{2}{|c|}{ Non-Millennial } & \multirow{2}{*}{$\mathbf{F}$} & \multirow{2}{*}{ Sig. } \\
\hline & Mean & S. D & Mean & S. D & & \\
\hline A. Awareness of environmental concerns & 3.70 & .46 & 3.49 & .64 & 1.552 & .220 \\
\hline $\begin{array}{l}\text { 1. We are approaching the limit of the number of people the earth cannot } \\
\text { support }\end{array}$ & 3.35 & .96 & 3.33 & 1.11 & .004 & .951 \\
\hline $\begin{array}{l}\text { 2. Humans have the right to modify the natural environment to suit their } \\
\text { needs }\end{array}$ & 2.52 & 1.22 & 2.59 & 1.06 & .037 & .847 \\
\hline $\begin{array}{l}\text { 3. When humans interfere with nature it often produces disastrous } \\
\text { consequences }\end{array}$ & 3.63 & .88 & 3.53 & 1.07 & .114 & .737 \\
\hline 4. Humans are severely abusing the environment & 4.15 & 1.06 & 3.76 & 1.25 & 1.183 & .283 \\
\hline $\begin{array}{l}\text { 5. The earth has plenty of natural resources if we just learn how to } \\
\text { develop them }\end{array}$ & 4.41 & 69 & 4.12 & .99 & 1.301 & .261 \\
\hline 6. Plants and animals have as much right as humans to exist & 4.44 & .70 & 4.12 & 1.22 & 1.284 & .264 \\
\hline $\begin{array}{l}\text { 7. The balance of nature is strong enough to cope with the impacts of } \\
\text { modern industrial nations }\end{array}$ & 2.89 & 1.37 & 2.65 & 1.06 & .385 & .538 \\
\hline $\begin{array}{ll}\text { 8. Despite our special abilities humans are still subject to the laws of } \\
\text { nature }\end{array}$ & 3.93 & .87 & 3.65 & .93 & 1.010 & .321 \\
\hline $\begin{array}{l}\text { 9. The so-called "ecological crisis" facing humankind has been greatly } \\
\text { exaggerated }\end{array}$ & 2.76 & 1.30 & 3.30 & 1.09 & 1.975 & .167 \\
\hline 10. The earth is like a spaceship with very limited room and resources & 3.56 & 1.12 & 3.47 & 1.18 & .058 & .811 \\
\hline 11. Humans were meant to rule over the rest of nature & 3.18 & .97 & 3.78 & 1.07 & 3.672 & .062 \\
\hline 12. The balance of nature is very delicate and easily upset & 3.76 & 1.07 & 3.70 & .97 & .036 & .849 \\
\hline $\begin{array}{l}\text { 13. Humans will eventually learn enough about how nature works to be } \\
\text { able to control it }\end{array}$ & 3.33 & 1.04 & 3.24 & 1.20 & .082 & .775 \\
\hline 14. The effects of pollution on public health are worse than we realize & 4.26 & .86 & 4.18 & 1.19 & .072 & .790 \\
\hline $\begin{array}{l}\text { 15. If things continue on their present course, we will soon experience a } \\
\text { major ecological catastrophe }\end{array}$ & 4.22 & .75 & 4.00 & 1.17 & .590 & .447 \\
\hline B. Acceptance of hotel green practice & 4.02 & .59 & 3.68 & .41 & 4.197 & $.047 *$ \\
\hline 1. I prefer using silverware tableware repeatedly in hotels. & 3.74 & .90 & 3.47 & .94 & .903 & .347 \\
\hline 2. I support and participate in waste-recycling ideas in hotels. & 4.44 & .75 & 4.12 & .70 & 2.086 & .156 \\
\hline $\begin{array}{l}\text { 3. Guest rooms should include water-saving devices (for example, water- } \\
\text { saving shower\& water-saving toilets). }\end{array}$ & 4.37 & .93 & 4.53 & .62 & .388 & .537 \\
\hline 4. I support the use of automatic switches when no one is in a guest room. & 4.48 & .80 & 4.53 & .62 & .044 & .835 \\
\hline $\begin{array}{l}\text { 5. I mind using products made from recyclable materials when I am in a } \\
\text { hotel. }\end{array}$ & 2.71 & 1.48 & 3.26 & 1.31 & 1.584 & .215 \\
\hline $\begin{array}{l}\text { 6. I prefer the use of shampoo refillable dispensers in hotels than small } \\
\text { plastic bottles when I am in a hotel. }\end{array}$ & 4.07 & 1.04 & 3.53 & .94 & 3.088 & .086 \\
\hline 7. I support that guest rooms use special low-energy light bulbs. & 4.22 & .93 & 3.71 & .99 & 3.058 & .088 \\
\hline $\begin{array}{l}\text { 8. Training hotel employees for a better environmental performance is } \\
\text { fundamental. }\end{array}$ & 4.44 & .75 & 4.35 & .61 & .179 & 675 \\
\hline 9. I prefer hotels depending on solar energy rather than electricity. & 4.19 & .96 & 3.59 & .94 & 4.088 & $.049 *$ \\
\hline $\begin{array}{l}\text { 10. All hotels should participate in environmental programs and obtain } \\
\text { green certifications }\end{array}$ & 4.33 & .83 & 4.18 & .64 & .441 & .510 \\
\hline $\begin{array}{l}\text { 11. I mind exchanging my bed sheets every three days, instead of everyday, } \\
\text { when I am in a hotel }\end{array}$ & 2.82 & 1.32 & 3.30 & 1.19 & 1.438 & .237 \\
\hline $\begin{array}{l}\text { 12. The water of swimming pools should be used to water hotel landscape } \\
\text { and green areas }\end{array}$ & 4.30 & .78 & 4.18 & 1.41 & 3.887 & .515 \\
\hline $\begin{array}{l}\text { 13. I mind sorting my room waste and putting it in recycling bins when I } \\
\text { am in a hotel. }\end{array}$ & 4.04 & .85 & 3.59 & 1.28 & 1.958 & .169 \\
\hline It prefer turning off the air conditioner in hotel open- air areas. & 3.04 & 1.40 & 2.76 & 1.39 & .396 & .532 \\
\hline C. Willingness to pay & 3.44 & 1.22 & 2.82 & 1.01 & 3.064 & .087 \\
\hline $\begin{array}{l}\text { 1. It is acceptable for me to pay more for a hotel that engages in green } \\
\text { practices. }\end{array}$ & 3.59 & 1.22 & 3.00 & 1.17 & 2.542 & .118 \\
\hline $\begin{array}{l}\text { 2. I am willing to pay an extra percentage on my hotel bill to support the } \\
\text { hotel's efforts to be environmental-friendly }\end{array}$ & 3.44 & 1.22 & 2.65 & .93 & 5.301 & $.026^{*}$ \\
\hline
\end{tabular}


Similarly, Han et al. (2009) revealed that age has a significant moderating role in buying behaviors; younger individuals are likely to be more innovative when adopting a new product or service, as opposed to older more conservative people. On the other side, Canela \& Navarro (2017) assumed as customers get older and become more mature they will be more likely to purchase responsible products. However, Li et al. (2017) found no significance difference among different age groups (young and old) regarding attitude towards green behaviors.

In detail, the most significant responses of both age groups were depicted in statements (2), (3), (4) and (8). Statement (2) "I support and participate in waste-recycling ideas in hotels" recorded a mean $=4.4$ and 4.12 , for Millennials and Non-Millennials, respectively. This indicated a high acceptance level of waste recycling ideas; however, their response in statement (13) "I mind sorting my room waste and putting it in recycling bins when I am in a hotel", was contradicting, as it was obvious that both groups would not prefer to put much effort to participate in implementing these ideas. A finding that comes in agreement with Goodwin \& Francis (2003), Manaktola \& Jauhari (2007) and Elfeel (2017) who reached to the same result: customers may want to be environmentally responsible but still want to maintain their existing life-style, and they are not ready to sacrifice their convenience.

Statements (3), (4), (8) and (10) recorded the highest means for both groups. Interestingly, these statements showed that both groups encouraged most the green practices that would not degrade their convenience and recreation experience. According to Elfeel (2017), Egyptian hotel customers are aware of their environmental challenges, but they do nothing in this regard; they expect the government to improve their standards of living before focusing on going green. Millennials showed higher means in willingness to pay more for hotel green practices. However, no significant difference was depicted in this construct between both groups (Sig. $=0.087$ ). Thus, $\mathrm{H} 3$ can be partially supported. This agrees with Lita et al. (2014) their study showed that the majority of those showing higher levels of understanding about the importance of preserved natural environment were young people between 2130 years old, who were ready to pay premium as well. On the contrary, Canela \& Navarro (2017) revealed that the willingness to pay more for the services of an environmentally responsible hotel was greater among older people.

Green hotel customers are usually charged premium in order for hotels to recover addition costs incurred in the production, marketing and disposal. This includes initial set-up costs of new or alternative more environmentallyconscious production and distribution approaches. According to Elfeel (2017), green hotels need to recover the indirect costs of not achieving economies of scale. In the same context, Lita et al. (2014), as well as, Canela \& Navarro (2017) argue that pricing for green practices should consider customers' sensitivities to additional costs incurred by implementing green initiatives.

Spearman correlation was also applied to detect the correlation among research variables. Results depicted a significant correlation between Millennials acceptance of hotel green practices and willingness to pay more for them. $\mathrm{R}=0.575$ and $\mathrm{P}$ value $=0.002$ as shown in Table (2). Meanwhile, no significant correlation was found between Millennials environmental awareness and their acceptance of hotel green practices. Millennials environmental awareness is not 
significantly related to their willingness to pay more for green hotels, as well.

Table 2: Spearman correlation among research variables

\begin{tabular}{|c|c|c|c|c|}
\hline & & 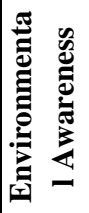 & 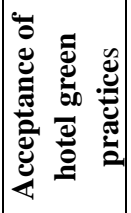 & 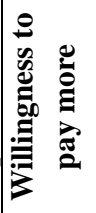 \\
\hline \multirow{2}{*}{$\begin{array}{c}\text { Environmental } \\
\text { awareness }\end{array}$} & $\begin{array}{c}\text { Pearson } \\
\text { Correlation }\end{array}$ & \multirow[t]{2}{*}{--} & .187 & .157 \\
\hline & Sig. (2-tailed) & & .350 & .435 \\
\hline \multirow{2}{*}{$\begin{array}{c}\text { Acceptance of } \\
\text { hotel green } \\
\text { practice }\end{array}$} & $\begin{array}{c}\text { Pearson } \\
\text { Correlation }\end{array}$ & \multirow[t]{2}{*}{--} & \multirow[t]{2}{*}{--} & $\begin{array}{c}.575 * \\
*\end{array}$ \\
\hline & Sig. (2-tailed) & & & .002 \\
\hline \multirow{2}{*}{$\begin{array}{l}\text { Willingness to } \\
\text { pay more }\end{array}$} & $\begin{array}{c}\text { Pearson } \\
\text { Correlation }\end{array}$ & \multirow[t]{2}{*}{--} & \multirow[t]{2}{*}{--} & \multirow[t]{2}{*}{--} \\
\hline & Sig. (2-tailed) & & & \\
\hline
\end{tabular}

**. Correlation is significant at the 0.01 level (2-tailed).

H4 anticipated that Millennials' environmental awareness level will significantly impact their acceptance of hotel green practices. One-way ANOVA test was used to investigate the impact of different awareness levels on customers' acceptance of hotel green practices, as shown in table (3). Results of the test indicated that the difference in awareness level does not influence customers' acceptance of the hotel green practices $(\mathrm{F}=.500 ; \mathrm{P}$ value $=$ $.615)$. Figure (1) also illustrates the mean plot for impact of difference in awareness level on acceptance of hotel green practices. . Thus, H4: "Millennials' environmental awareness level will significantly impact their acceptance of hotel green practices" is unsupported.

Table 3: One-way ANOVA for impact of difference in awareness level on acceptance of hotel green practices

\begin{tabular}{|c|c|c|c|c|c|c|c|}
\hline \multirow{2}{*}{ 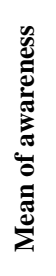 } & \multirow{2}{*}{ 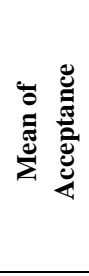 } & \multirow{2}{*}{ 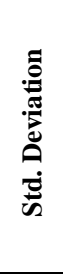 } & \multirow{2}{*}{ 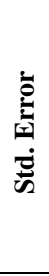 } & \multicolumn{2}{|c|}{ 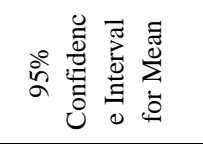 } & \multirow{2}{*}{ 山 } & \multirow{2}{*}{$\dot{80}$} \\
\hline & & & & 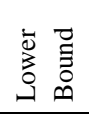 & 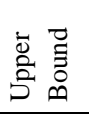 & & \\
\hline$\underset{\sim}{\stackrel{్}{~}}$ & 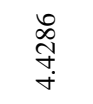 & 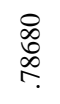 & ্ֻণ & 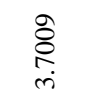 & $\begin{array}{l}\text { ర్ } \\
\stackrel{n}{n} \\
\stackrel{n}{n}\end{array}$ & \multirow{4}{*}{ : } & \multirow{4}{*}{$\frac{n}{6}$} \\
\hline$\underset{+}{\stackrel{8}{+}}$ & 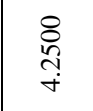 & 离 & 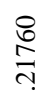 & $\underset{\text { ㄱ. }}{\mathbb{E}}$ & 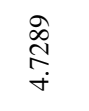 & & \\
\hline$\underset{i}{\stackrel{8}{0}}$ & $\begin{array}{l}8 \\
8 \\
\dot{0} \\
\text { in }\end{array}$ & & & & & & \\
\hline స్్ّ & 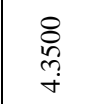 & 量 & $\begin{array}{l}\text { 융 } \\
\end{array}$ & $\begin{array}{l}\frac{m}{8} \\
\dot{\sigma}\end{array}$ & $\begin{array}{l}0 \\
\stackrel{\infty}{0} \\
\dot{+}\end{array}$ & & \\
\hline
\end{tabular}

In Robinot \& Giannelloni (2010) German and English tourists saw that the natural environment played a large role in their choice of tourist destination and especially in their choice of accommodation. Lita et al. (2014) findings confirmed that respondents with more favorable beliefs about the value provided by green hotels were likely to participate in green activities during their stay.

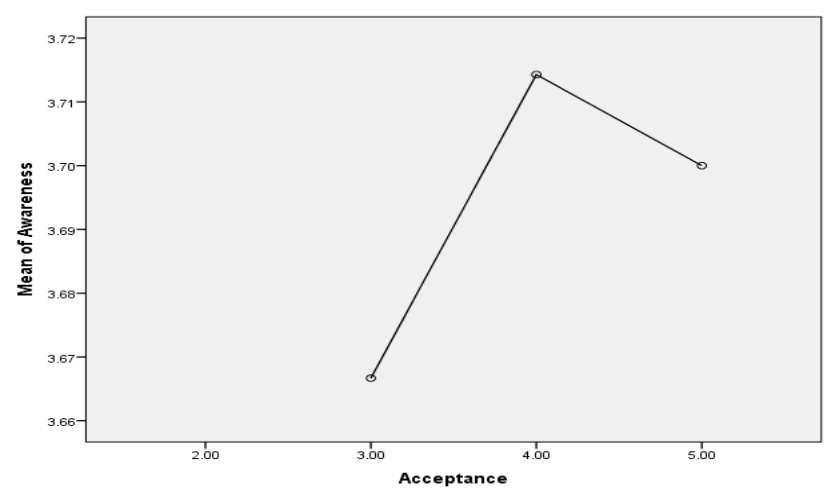

Figure 1: Mean plot for impact of difference in awareness level on acceptance of hotel green practices

H5 predicted that Millennials' environmental awareness level will significantly impact their willingness to pay more. One-way ANOVA test was also used to investigate the impact of different awareness levels of customers on 
their willingness to pay more for hotel green practices, as shown in table (4). Results of the test indicated the difference in awareness level does not influence customers' willingness to pay more $(\mathrm{F}=.686 ; \mathrm{P}$ value $=.569)$. Figure $(2)$ illustrates the mean plot for impact of difference in awareness level on willingness to pay more for hotel green practices. Thus, H5: "Millennials' environmental awareness level will significantly impact their willingness to pay more" is unsupported.

Table 4: One-way ANOVA for impact of difference in awareness level on willingness to pay more

\begin{tabular}{|c|c|c|c|c|c|c|c|}
\hline \multirow{2}{*}{ 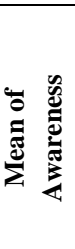 } & \multirow{2}{*}{ 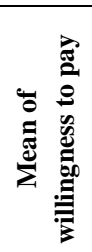 } & \multirow{2}{*}{ 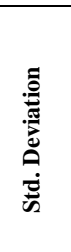 } & \multirow{2}{*}{ 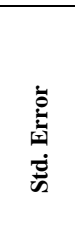 } & \multicolumn{2}{|c|}{$\begin{array}{l}\text { 95\% Confidence } \\
\text { Interval for Mean }\end{array}$} & \multirow[b]{2}{*}{ ⿷匚 } & \multirow[b]{2}{*}{$\stackrel{50}{50}$} \\
\hline & & & & ف요 & 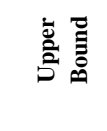 & & \\
\hline 2.00 & 2.0000 & . & . & & . & \multirow{5}{*}{$\begin{array}{l}.68 \\
6\end{array}$} & \multirow{5}{*}{.569} \\
\hline 3.00 & 3.2778 & $\begin{array}{l}1.394 \\
43\end{array}$ & $\begin{array}{l}.4648 \\
1\end{array}$ & 2.2059 & 4.3496 & & \\
\hline 4.00 & 3.5667 & $\begin{array}{l}1.193 \\
23\end{array}$ & $\begin{array}{l}.3080 \\
9\end{array}$ & 2.9059 & 4.2275 & & \\
\hline 5.00 & 4.0000 & .00 & .00 & 4.00 & 4.00 & & \\
\hline Total & 3.4444 & $\begin{array}{l}1.219 \\
50\end{array}$ & $\begin{array}{l}.2346 \\
9\end{array}$ & 2.9620 & 3.9269 & & \\
\hline
\end{tabular}

This is contradictory to the study of Tsai $\&$ Tsai (2008) and Kang et al. (2012) who found a positive relationship between the level of environmental concern and willingness to pay premium for hotels' green initiatives. Meanwhile, Han et al. (2009) study implied that customers having eco-friendly behaviors are willing to stay at a green hotel, to recommend it and to pay more for it.

In the same context, Garikapati, et al. (2016) explained that tourist willingness to pay for environmental protection was found from those who were young, had relatively high levels of income and were from Englishspeaking nations. On the other side, the study of Kang et al (2012) found that although some tourists are supporting environmental sustainability, they believe that the hotel has the responsibility to fund those initiatives and are not willing to pay extra.

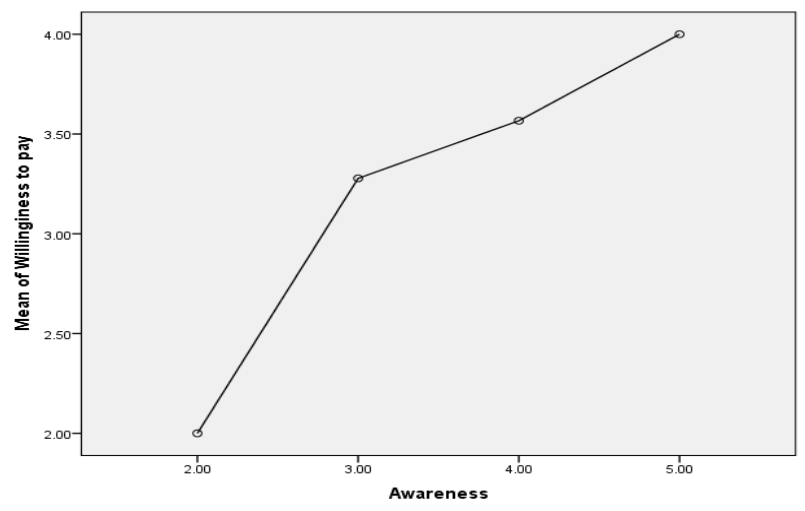

Figure 2: Mean plot for impact of difference in awareness level on willingness to pay more

In accordance with Mostafa (2007) environmental concerns are a post-material value; a set of attitudes that develop among wealthy people once the more basic needs of food and safety have been met. In Tsai \& Tsai (2008) and Harti \& Munandar (2017) environmental concerns are also believed to be increasingly driving customer choice and decisions in Western and Northern Europe, although this is still not the case in Central and Eastern Europe.

Elfeel (2017) and Attallah \& El-Mawardy (2018) discussed how Egyptian consumers are price sensitive, which can be a barrier especially when the quality is contrasted with non-green hotels. Consumers care about environmental problems when their basic needs have been met in the first place. Interestingly, this ideology can be totally supported in developing countries, where the 
economic status of individuals is the driving force for their purchasing behaviors.

H6 anticipated that Millennials' acceptance of hotel green practices level will significantly impact their willingness to pay more. One-way ANOVA test indicated that the difference in acceptance level of hotel green practices does influence customers' willingness to pay more $(\mathrm{F}=4.554 ; \mathrm{P}$ value $=.014)$, as shown in table (5).

Table 5: One-way ANOVA for impact of difference in acceptance of hotel green practices on willingness to pay more

\begin{tabular}{|c|c|c|c|c|c|c|c|}
\hline \multirow{2}{*}{ 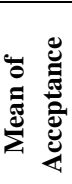 } & \multirow{2}{*}{ 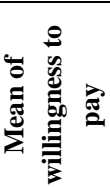 } & \multirow{2}{*}{ 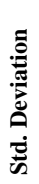 } & \multirow{2}{*}{ 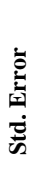 } & \multicolumn{2}{|c|}{$\begin{array}{l}\text { 95\% Confidence } \\
\text { Interval for Mean }\end{array}$} & \multirow[b]{2}{*}{$\mathbf{F}$} & \multirow[b]{2}{*}{ Sig. } \\
\hline & & & & $\begin{array}{l}\text { Lower } \\
\text { Bound }\end{array}$ & $\begin{array}{l}\text { Upper } \\
\text { Bound }\end{array}$ & & \\
\hline 2.00 & 2.00 & . & . & . & . & \multirow{5}{*}{\begin{tabular}{l}
\multirow{n}{n}{} \\
$\stackrel{+}{+}$
\end{tabular}} & \multirow{5}{*}{$\stackrel{*}{\stackrel{*}{\sigma}}$} \\
\hline$\underset{\dot{m}}{\stackrel{\partial}{ }}$ & in & $\frac{n}{n}$ & 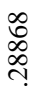 & 1.5813 & 3.4187 & & \\
\hline$\underset{+}{\stackrel{一}{+}}$ & $\stackrel{\hat{N}}{r}$ & 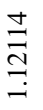 & 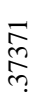 & 2.4160 & 4.1396 & & \\
\hline$\underset{i}{8}$ & $\stackrel{m}{+}$ & $\begin{array}{l}\infty \\
0 \\
\infty \\
0 \\
0 \\
0\end{array}$ & \&ి & 3.6214 & 4.9786 & & \\
\hline 要 & $\tilde{n}$ & 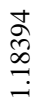 & 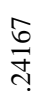 & 3.0209 & 4.0208 & & \\
\hline
\end{tabular}

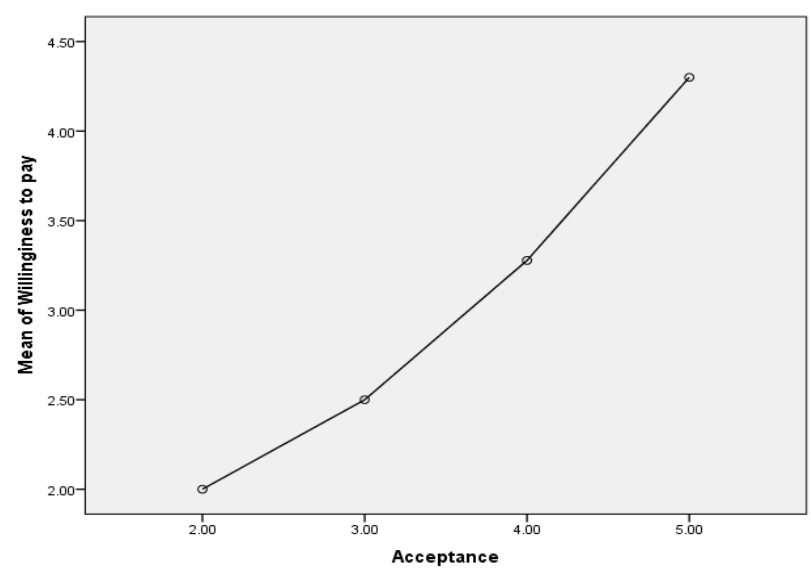

Figure 3: Mean plot for impact of difference in acceptance of hotel green practices on willingness to pay more
Figure (3) illustrates the mean plot for impact of difference in acceptance level of hotel green practices on willingness to pay more for them. Thus, H6: "Millennials' acceptance of hotel green practices level will significantly impact their willingness to pay more" is supported.

According to Attallah \& El-Mawardy (2018), Egyptian Millennials will expect the services they purchase to be economically, socially and environmentally responsible; a viewpoint that is in agreement with Goodwin \& Francis (2003), Canela \& Navarro (2017) and Li et al. (2017).

It is apparent that customers see environmental practices as an obligation that should be funded by the hotel itself and the cost should not be added to hotel prices; they worry about peaceful coexistence with the natural environment, but are also swayed by expectations for the economy and hopes that the natural environment can recover a sense of balance on its own. (Lita et al., 2014; Jung et al., 2016 and Sziva \& Zoltay, 2016) In addition, Manaktola \& Jauhari (2007) found that although hotel customers in India have environmental concerns and prefer hotels that conduct green initiatives, they are not willing to pay extra for those initiatives. Meanwhile, Bastawroos (2017) suggested that Millennials are known to be digital natives and will pay more if they feel they are making a difference in the world.

\section{Conclusion and Implications}

The hospitality industry in Egypt ultimately depends on the support and appreciation of the market to be able to face its environmental challenges. Yet Egyptian hotel market is still at the stage where their recognition of green hotels is only an economic behavior; price and quality remain the dominant factors that influence what customers actually demand. 
Therefore, it would not be wise to neglect the current economic status of Egyptians.

Millennials, constituting more than $43 \%$ of the Egyptian society, were found to have noticeable level of environmental awareness but lack commitment to tolerating hotel green practices and are not yet ready to willing to sacrifice parts of their current lifestyles. Furthermore, recognition of green hotels is based on economic matters; and if green hotels are seen as a relatively expensive product, conflicts with cost considerations may occur. Besides, Millennials want to know they are getting their money's worth, as they are willing to pay higher prices if they can be ensured they will have the unforgettable experiences they long for. However, environmental positioning alone is not sufficient to guarantee product success, and might not be influential in some societies.

Thus, In societies where governments may not have the means or the priorities to regulate and enforce legislation for environmental protection, comes the role of tourism developers and hoteliers to attract the market to green lodging properties.

Hotels are recommended to deliver information that shows customers how their behavior changes (e.g., energy conservation, recycling) could contribute to a quantifiable decrease in environment impacts. Marketers in a green hotel should educate customers about why it is healthy and beneficial to select a green hotel. For instance, marketers can educate current/potential customers about the health environment of a green hotel (e.g., fresh air with a natural scent, non-chemical base amenities, availability of organic food, environmental cleaning for laundry, or cotton towels and linens, etc.) as a customer attraction strategy.
Meanwhile, pricing for green hotel services and products should be done carefully to face customers' sensitivity to additional costs.

"Let numbers speak for you"; is a recommended approach for hoteliers. Quantifying the result of water and energy savings and displaying it to guests during their stay would encourage them to put efforts and help. Some hotels put a sign in its dining outlets declaring "yesterday' food waste" and how it could alternatively feed people in need. Empowering the market by making it feel part of greening initiatives can be of great benefit.

\section{REFERENCES}

- Abdel Wahab, R. (2003). Sustainable Development and environmental impact assessment in Egypt: Historical Assessment. The Environmentalist, 23, pp.49-70.

- Attallah, N. and El-Mawardy, G. (2018). The Reciprocal Relationship between Generation Y (Millennials) and creative Tourism with application on Egypt. Journal of Tourism Research, 20, pp. $66-77$.

- Bastawroos, J. (2017). Brand Managers Perspective on Innovative Strategies to attract Millennials, Masters Thesis, Faculty of California State Polytechnic University, Pomona.

- Canela, J. and Navarro, M. (2017). Profile of the consumer who values responsible and smart tourism in the hotel industry. Management Decision, 50(5), pp. 972-988.

- Caroll, J. (2016). Future Trends in the Hospitality Industry: Millennials and Social Media Rule. B2B Marketing \& Strategy, (October).

- Central Agency for Public Mobilization and Statistics - Egypt.(CAPMAS, 2016)

- Chen, M.F. and Tung, P.J. (2010). The moderating effect of perceived lack of facilities on consumers' recycling intentions. Environmental Behaviour, 42 (6), pp. 824-844.

- El Demerdash, J. (2016). Waste Management in Food \& Beverage Operations: The Case of Alexandria. Refereed Proceedings of 9th 
International Conference. Faculty of Tourism \& Hotels, Fayoum University.

- El Demerdash, J. and Mostafa, L. (2013). Exploring Obstacles of Employing Environmental Practices: The Case of Egyptian Green Hotels. Journal of Human resources in Hospitality \& Tourism, 12(3), pp.243-258.

- Elfeel, S. (2017). A Comparative Assessment of Green Practices of Certified and NonCertified Green Hotels in Egypt. Masters Thesis, Department of Hotel Studies. Alexandria University.

- Garikapati, M., Pendyala, M., Morris, A., Mokhtarian, P.L. and McDonald, N. (2016). Activity patterns, time use, and travel of Millennials: a generation in transition. Transport Reviews, 36(5), pp. 558-584.

- Goodwin, H. and Francis, J. (2003). Ethical and responsible tourism: Consumer trends in the UK. Journal of Vacation Marketing, 9(3), 2003, pp. 271-284.

- Green Hotel Association (2010), [online]. Available from: http://www.greenhotels.com/pressrel.php\#a2 [Accessed 18 ${ }^{\text {th }}$ December, 2017]

- Hamed, H. (2017). Marketing Destinations to Millennials: Examining the Compatibility between the Destination Marketing Organization Website and the Millennial Tourist Prospects. Journal of Tourism and Recreation, 3(1), pp. 1-20.

- Han, H. and Yoon, H. (2015). Hotel customers' environmentally responsible behavioral intention: Impact of key constructs on decision in green consumerism. International Journal of Hospitality Management, (45), pp. 22-33.

- Han, H., Hsu, L. and Sheu, C. (2010). Application of the Theory of Planned Behavior to green hotel choice: Testing the effect of environmental friendly activities. Tourism Management, (31), pp. 325-334.

- Han, H., Hsu, L.T. and Lee, J.S. (2009). Empirical Investigation of the Roles of Attitudes toward Green Behaviors, Overall Image, Gender, and Age in Hotel Customers' Eco-Friendly Decision-Making Process. International Journal of Hospitality Management, (28), pp.519-528.

- Harti, U. and Munandar, D. (2017). "Modernity and Lifestyle: Analysis of Generation Y on Creative Industry Product. The Social Sciences, 12(1), pp.160-166.
- Johnson, L., (2017). Millennials Perception of Destination Attractiveness, Masters Thesis, Department of Tourism, Conventions, and Event Management. Indiana University.

- Jung, S., Lee, S. and Dalbor, M. (2016). The negative synergistic effect of internationalization and corporate social responsibility on US restaurant firms' value performance. International Journal of Contemporary Hospitality Management, 28 (8), pp.1759-1777.

- $\quad$ Kang, K., Stein, L, Heo, C. and Lee, S. (2012). Consumers' willingness to pay for green initiatives of the hotel industry. International Journal of Hospitality Management, 31, pp.564-572.

- Kasim, A. (2008). BESR in the Hotel Sector: A Look at Tourists' Propensity Towards Environmentally and Socially Friendly Hotel Attributes. International Journal of Hospitality \& Tourism Administration, 5(2), 61-83.

- Lee, K. (2008). Opportunities for green marketing: young consumers. Marketing Intelligence \& Planning, 26 (6), pp.573-586.

- Li, Y., Fang, S. and Huan, T. (2017). Consumer response to discontinuation of corporate social responsibility activities of hotels. International Journal of Hospitality Management, (64), pp. 41-50.

- $\quad$ Lita, R., Surya, S., Ma'ruf, M. and Syahrul, L. (2014). Green Attitude and Behavior of Local Tourists towards Hotels and Restaurants in West Sumatra, Indonesia. Procedia Environmental Sciences (20), pp. 261- 270.

- Manaktola, K. And Jauhari, V. (2007). Exploring Consumer Attitude and Behavior towards Green Practices in the Lodging Industry in India. International Journal of Contemporary Hospitality Management, 19(5), pp.364-377.

- Mboga, J. (2017). Ethical Sourcing to ensure Sustainability in the Food and Beverage Industry and Eliciting Millennial Perspectives. European Journal of Economic and Financial Research, 2(4), pp.97-117.

- Mostafa, M. (2007). Gender differences in Egyptian consumers' green purchase behaviour: the effects of environmental knowledge, concern and attitude. International Journal of Consumer Studies, (31), pp.220229. 
- Naumovska, L. (2017). Marketing Communication Strategies for GenerationY Millennials. Business Management and Strategy, 8(1), pp.123-133.

- Robinot, E. and Giannelloni, J. (2010), "Do hotels' "green" attributes contribute to customer satisfaction?" Journal of Services Marketing. 24 (2), pp.157-169.

- $\quad$ Sziva, I. and Zoltay, R. (2016). How Attractive Can Cultural Landscapes Be for Generation Y? Journal of Tourism, Culture and Territorial Development, 7(14), pp.1-16.

- Tilikidou, I. Delistavrou, A. and Sapountzis, N. (2014). Customers' Ethical Behaviour towards Hotels. Procedia Economics and Finance, (9), pp. 425 - 432.

- Tsai, C.W. and Tsai, C.P. (2008). Impacts of Consumer Environmental Ethics on Consumer Behaviors in Green Hotels. Journal of Hospitality \& Leisure Marketing, 17(3-4), pp. 284, 313. 